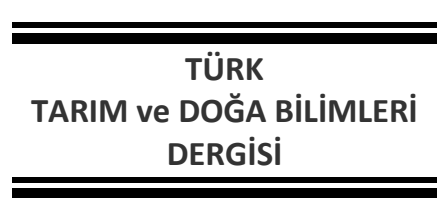

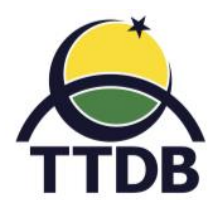

www.dergipark.gov.tr/turkjans

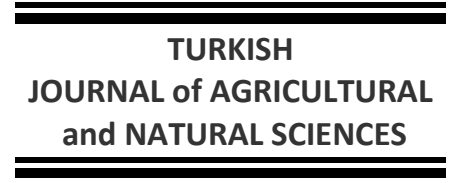

Araştırma Makalesi

\title{
Kırşehir Illindeki Bazı Tarım Topraklarının Verimlilik Durumlarının Belirlenmesi
}

\author{
Ahu Alev ABACI BAYAR ${ }^{1 *}$, Murat ÇINARLI², Gamze BAKIR GÜVEN ${ }^{2}$ \\ ${ }^{1}$ Kırşehir Ahi Evran Üniversitesi, Toprak Bilimi ve Bitki Besleme Bölümü, Kırşehir \\ ${ }^{2}$ Kırşehir Ahi Evran Üniversitesi, Merkezi Araştırma ve Uygulama Laboratuvarı, Kırşehir \\ *Sorumlu yazar: ahu.abaci@ahievran.edu.tr
}

\begin{abstract}
Geliş Tarihi: 06.03.2019
Düzeltme Geliş Tarihi: 01.07.2019

Kabul Tarihi: 31.07.2019

Özet

Bu araştırma Orta Anadolu Masifinin bir parçası olan Kırşehir ilinin merkez ilçesine bağlı Saraycık köyünde yürütülmüştür. Alan topraklarının fiziksel ve kimyasal özellikleri ile bitki besin maddesi içeriklerini tespit etmek amacıyla arpa, buğday, nohut, kavun-karpuz tarımı yapılan 36 noktadan 0-30 cm derinliklerinden toprak örnekleri alınmıştır. Çalışma alanı topraklarının tekstürü kumlu tın, pH'sı 7.04-8.16 aralığında ve ortalama 7.77 olarak bulunmuş ve hafif alkalindir. Topraklarda tuzluluk problemi olmayıp, organik madde içeriği \%1.22-3.34 aralığında ve ortalama \%2.32 olarak orta seviyede, toplam kireç içeriği \%1.50-24.41 aralığında ve ortalama \%12.24 olarak orta derecede kireçli bulunmuştur. Alandaki yeterli ve noksan bulunan makro ve mikro besin elementi içeren alanlar tespit edilmiş ve istatistiki analizler sonucunda parametrelerin birbiri ile olan ilişkileri incelenmiştir. Sonuç olarak; toprakların 4.31-23.02 kg da-1 $\mathrm{P}_{2} \mathrm{O}_{5}$ aralığında ve ortalama $8.06 \mathrm{~kg} \mathrm{da}^{-1} \mathrm{P}_{2} \mathrm{O}_{5}$ olduğu orta seviyede fosfor içerdiği, potasyum $\left(\mathrm{K}_{2} \mathrm{O}\right)$ miktarı $80.62-459.80 \mathrm{~kg} \mathrm{da}^{-1}$ aralığında ve ortalama $181.70 \mathrm{~kg} \mathrm{da}^{-1}$, magnezyum (Mg) miktarı \%0.018-0.333 aralığında ve ortalama \%0.063, kalsiyum (Ca) miktarı \%0.425-3.475 aralığında ve ortalama \%0.953 olarak topraklarda yeterli seviyede bazı makro bitki besin elementi olduğu bulunmuştur. Tarım topraklarının bazı mikro besin elementlerinden bakır (Cu) miktarı 0.61-1.89 mg kg-1 aralığında ve ortalama 1.09 $\mathrm{mg} \mathrm{kg}$-1 olarak yeterli düzeyde bulunurken, mangan (Mn) miktarı 0.32-5.73 $\mathrm{mg} \mathrm{kg}^{-1}$ aralığında ve ortalama 2.77 $\mathrm{mg} \mathrm{kg}^{-1}$, alınabilir çinko (Zn) içeriği 0.13-0.77 mg kg-1 aralığında ve ortalama $0.37 \mathrm{mg} \mathrm{kg}^{-1}$ ve demir (Fe) içeriği 0.24$0.97 \mathrm{mg} \mathrm{kg}^{-1}$ aralığında ve ortalama $0.46 \mathrm{mg} \mathrm{kg}^{-1}$ olarak topraklarda düşük seviyede tespit edilmiştir.
\end{abstract}

Anahtar kelimeler: Verimlilik, besin elementleri, gübreleme, toprak tahlili, toprak, Kırşehir.

\section{Determination of Fertility Status of Some Agricultural Soils in Kirsehir Province}

\begin{abstract}
This study of Central Anatolia Massif connected to the central district of Kırsehir, which is part of the village was carried out in Saraycik. In order to determine the physical and chemical properties and plant nutrient contents of the field soils, soil samples were taken from 0-30 cm depths from 36 points where barley, wheat, chickpea, melon and watermelon were cultivated. The texture of the soil in the study area is sandy loam, $\mathrm{pH}$ is in the range of 7.04-8.16 and is found to be 7.77 on average and is slightly alkaline. There was no salinity problem in the soils and the organic matter content was found to be moderate in the range of $1.22-3.33 \%$ and average of $2.32 \%$, total lime content in the range of $1.50-24.41 \%$ and average of $12.24 \%$. Adequate and deficient macro and micro nutrient points were determined in the field and the relationships between the parameters were examined as a result of statistical analysis. As a result; the soil is in the range of 4.31-23.02 $\mathrm{kg} \mathrm{da}^{-1} \mathrm{P}_{2} \mathrm{O}_{5}$, the average is $8.06 \mathrm{~kg} \mathrm{da}^{-1} \mathrm{P}_{2} \mathrm{O}_{5}$ and it contains moderate phosphorus, the amount of potassium $\left(\mathrm{K}_{2} \mathrm{O}\right)$ in the range of $80.62-459.80 \mathrm{~kg} \mathrm{da}^{-1}$ and an average of $181.70 \mathrm{~kg} \mathrm{da}^{-1}$, the amount of magnesium $(\mathrm{Mg})$ in the range of 0.018 $0.333 \%$ and the average of $0.063 \%$, the amount of calcium (Ca) in the range of $0.425-3.475 \%$ and the average of $0.953 \%$, it was found that there is sufficient macro plant nutrients in soils. While the amount of copper (Cu) from some micro nutrients of agricultural soils is between $0.61-1.89 \mathrm{mg} \mathrm{kg}^{-1}$ and $1.09 \mathrm{mg} \mathrm{kg}^{-1}$ is sufficient in average, the amount of manganese $(\mathrm{Mn})$ is in the range of $0.32-5.73 \mathrm{mg} \mathrm{kg}^{-1}$ and $2.77 \mathrm{mg} \mathrm{kg}^{-1}$ on average, the
\end{abstract}


zinc $(\mathrm{Zn})$ content is in the range of $0.13-0.77 \mathrm{mg} \mathrm{kg}^{-1}$ and the average is $0.37 \mathrm{mg} \mathrm{kg}^{-1}$ and the iron (Fe) content is 0.24-0.97 $\mathrm{mg} \mathrm{kg}^{-1}$ in the range and average of $0.46 \mathrm{mg} \mathrm{kg}^{-1}$ was found to be low in the soil.

Keywords: Productivity, nutrient elements, fertilization, soil analysis, soil, Kirsehir.

\section{Giriş}

İnsanoğlu tarımla uğraşmaya başladığından beri toprağı işlemiş, bunun için çaba sarf etmiş ve en yüksek verimi almak istemiştir. Ancak hızlı nüfus artışı ile birlikte, üretilen tarım ürünlerinin yetersiz olduğu ortaya çıkmıştır. Keza günümüzde nüfusun hızlı artması ve tarım arazilerinin sınırlı sayıda ve elverişli olması sebebiyle birim alandan daha yüksek verim alınması yönünde çalışmalar başlamıştır. Tarım topraklarının verimliliklerinin korunması ve sürdürülebilirliğinin olması gelecek nesiller için çok önemlidir.

Toprağı doğru şekilde kullanmak en önemli faktördür. Öncelikle kaliteli tohumun bulunması, toprak işlemenin zamanında yapılması, hastalık ve zararlılarla mücadelenin doğru ve zamanında yapılması, gübrelemenin doğru ve sulama şeklinin uygun zamanda gerçekleştirilmesi en önemli unsurlardandır (Tunçtürk ve Yıldırım, 2004). Türkiye topraklarının büyük bir kısmı tarım için ideal kabul edilen tınlı bünyedeki topraklardan oluşmakta, toprak pH'sı yüksek, organik madde içeriği az, kireç kapsamı yüksek, tuzsuz, potasyum değeri yüksek ve fosfor kapsamı yeterli ve yüksek olduğu belirlenmiştir (Eyüpoğlu, 1999; Dinç ve ark., 1988). Nedeni ise, ülkemizin içinde bulunduğu iklim kuşağı, jeolojik yapısı ve coğrafi konumu olarak nitelendirilebilir.

Toprağa uygulanan bilinçsizce aşırı gübre kullanımları toprak kirliliğine, yerüstü ve yeraltı sularının kirlenmesine, çeşitli canlıların zarar görmesine neden olmakta ve bunun sonucunda toprağın ve toprakta bulunan ürünün kalitesi düşmektedir (Parlak ve ark., 2008). Toprağın verimliliğini arttırmak, hem fazla kimyasal uygulamalara maruz bırakmamak hem de topraktaki bitkilerin sağlıklı bir şekilde büyüyüp gelişmelerini sağlayabilmek için dengeli bir gübrelemenin yapılması gerekmektedir. Bunun için yapılması gereken en önemli faaliyet toprak analizi yaptırarak toprağın isteği doğrultusunda gübreleme uygulamaktır. Böylece toprak gereğinden fazla kimyasal müdahaleye maruz kalmayacak verimliliğinde artış olduğu gözlenecektir. Bu nedenlerle birlikte toprak analizlerine gereken önem verilmeli ve tarım yapılan toprakların verimlilik durumları belirlenerek, bitkilerin türlerine göre verilecek gübrelerin çeşitleri ve miktarları tespit edilmelidir (Ateş ve Turan, 2015).

$$
\text { Toprağın özelliklerini belirten }
$$

parametrelerden biri olan toprak reaksiyonu $(\mathrm{pH})$, bitki gelişimi için önemli olup pH'nın bitki besin maddesi alımı, toksik iyonların suda çözünürlüğü ve mikroorganizma aktivitesi üzerine önemli etkisinin mevcut olduğu bildirilmiştir (Abacı Bayan, 2016; Yaraş ve Daşgan, 2012).

Başar (2001) Bursa ilinin farklı yörelerinde yaptığı çalışmada, 1018 adet toprak örneğinde analizler yapmış, toprakların orta bünyeli, tuzsuz, hafif ve kuvvetli alkalin, fosfor, potasyum ve organik madde miktarının düşük değerlerde olduğunu belirlemiştir. Başka bir çalışmada, Tekirdağ'da buğday bitkisinin ekili olduğu tarım arazisinde toprak analizi yapılarak ve toprak analizi yapılmadan uygulanan gübrelemenin fosfor yönünden karşılaştırılması yapılmış ve toprak analizi ile gübre verilmesinin daha sağlıklı olduğu belirlenmiştir (Kadakal, 1992). Karadavut ve ark. (2011)'nın toprakta makro ve mikro besin elementi analizi üzerine yaptıkları çalışmada, Konya ilinde fiğ yetiştirilen tarım arazilerinin çinko, azot ve fosfor eksikliğinin olduğu yapılan toprak analizleri sonucu bulunmuştur. Oruç (1994)'un Kazova yöresindeki kimyasal ilaç ve gübrelerin temini ve kullanımı üzerine yaptığı çalışmada, üreticilerin toprak analizi konusunda yanlış fikirlere sahip oldukları, üreticilerin \% 67.44'ünün yalnızca kendi tecrübelerine dayanarak gübreleme yaptıkları saptanmıştır. Üreticilerin \% 32.56'sının kendi tecrübelerinin yanı sıra gübreleme konusunda farklı kaynaklara başvurduğu belirtilmiştir. Kızılaslan ve ark. (2014), Gülaç (2011) ve Unay (2007) gibi birçok araştırıcı tarafından yapılan çalışmalarda bitkisel üretim faaliyetinde bulunan üreticilerin etkin ve bilinçli gübreleme yapmadığı, toprak tahlili yaptırmadan toprağa gübre verme eğiliminde olduğu, çiftçilerin ilkokul mezunu olduğu, genellikle aile büyüklerinin bilgilerine göre tarımsal faaliyetleri yaptıkları belirtilmiştir.

Yapılan birçok çalışmada toprakların, bitki besin elementi miktarları, toprak özellikleri ve verimlilik durumları incelenerek istatistiki olarak aralarındaki ilişkiler ortaya konulmuş ve potansiyel bitki besleme problemlerine çözüm önerileri geliştirilmiştir. Ekonomik kar sağlanması için alternatif ürünlerin veya çeşitlerin geliştirilmesi ve çok amaçlı olarak bölge çiftçisine örnek olabilecek toprak tahlillerinin yapılmasının gerek olduğu tespit edilmiştir (Demirer ve ark., 2003; Çimrin ve Boysan, 2006; Tümsavaş ve Aksoy, 2008; Çakıcı ve ark., 2012; Özyazıcı ve ark., 2013).

$\mathrm{Bu}$ çalışmada Kırşehir ili merkez ilçesine bağlı Saraycık köyünde tarım alanlarını temsil 
edecek şekilde alınan toprak örneklerinde fiziksel, kimyasal, bazı makro ve mikro besin elementi kapsamları belirlenmiş ve verimlilik düzeyleri ve ayrıca toprak analizi yapılan parametrelerin birbiriyle olan ilişkileri istatistiki olarak incelenmiştir.

\section{Materyal ve Yöntem}

Çalışma yapılan alan Kırşehir ili merkez ilçesine bağlı bulunan Saraycık Köyü olmuştur.
Alanda karasal iklim hüküm sürmektedir. Yıllık ortalama yağış miktarı 350-400 mm civarındadır. ì, Kızılırmak Havzası üzerinde olmasına rağmen bu havzadan yeterince yararlanamadığı görülmektedir. Çalışmanın yapıldığı alanın coğrafi olarak konumu Şekil 1'de, toprak örneklerinin alındığı arazilerdeki tarım ürünlerinin türü ise Tablo $1^{\prime}$ 'de gösterilmektedir.

Tablo 1. Çalışma alanı topraklarının ekili ürün çeşidi

\begin{tabular}{|c|c|c|c|}
\hline Bölge numarası & Toprak örneği numarası & Ekili ürün çeşidi & Örnekleme derinliği $(\mathrm{cm})$ \\
\hline \multirow{5}{*}{ I. Bölge } & 1 & Buğday & $0-30$ \\
\hline & 2 & Arpa & $0-30$ \\
\hline & 3 & Arpa & $0-30$ \\
\hline & 4 & Nadas & $0-30$ \\
\hline & 5 & Nohut & $0-30$ \\
\hline \multirow{5}{*}{ II. Bölge } & 6 & Nohut & $0-30$ \\
\hline & 7 & Arpa & $0-30$ \\
\hline & 8 & Buğday & $0-30$ \\
\hline & 9 & Arpa & $0-30$ \\
\hline & 10 & Arpa & $0-30$ \\
\hline \multirow{4}{*}{ III. Bölge } & 11 & Arpa & $0-30$ \\
\hline & 12 & Arpa & $0-30$ \\
\hline & 13 & Arpa & $0-30$ \\
\hline & 14 & Arpa & $0-30$ \\
\hline \multirow{7}{*}{ IV. Bölge } & 15 & Arpa & $0-30$ \\
\hline & 16 & Arpa & $0-30$ \\
\hline & 17 & Kavun-Karpuz & $0-30$ \\
\hline & 18 & Arpa & $0-30$ \\
\hline & 19 & Kavun-Karpuz & $0-30$ \\
\hline & 20 & Arpa & $0-30$ \\
\hline & 21 & Buğday & $0-30$ \\
\hline \multirow{5}{*}{ V. Bölge } & 22 & Arpa & $0-30$ \\
\hline & 23 & Arpa & $0-30$ \\
\hline & 24 & Arpa & $0-30$ \\
\hline & 25 & Arpa & $0-30$ \\
\hline & 26 & Nadas & $0-30$ \\
\hline \multirow{4}{*}{ VI. Bölge } & 27 & Arpa & $0-30$ \\
\hline & 28 & Arpa & $0-30$ \\
\hline & 29 & Arpa & $0-30$ \\
\hline & 30 & Arpa & $0-30$ \\
\hline \multirow{6}{*}{ VII. Bölge } & 31 & Arpa & $0-30$ \\
\hline & 32 & Arpa & $0-30$ \\
\hline & 33 & Arpa & $0-30$ \\
\hline & 34 & Buğday & $0-30$ \\
\hline & 35 & Kavun-Karpuz & $0-30$ \\
\hline & 36 & Nohut & $0-30$ \\
\hline
\end{tabular}

Araştırma alanı 2018 yılında tarım faaliyeti yoğunluğuna bağlı olarak 7 farklı bölgeye ayrılmıştır. Arpa, buğday, nohut, kavun ve karpuz bulunan 10 dekar ve üzeri büyüklükteki 36 adet tarım alanından genel kurallara uygun olarak (Jackson, 1958), 0-30 $\mathrm{cm}$ derinlikten paslanmaz çelik kürek ile toprak örnekleri alınmıştır. Alınan bu toprak örnekleri köyün tarım arazisini genel olarak ifade edecek şekilde toplanmıştır. Toprak örnekleri Ahi Evran Üniversitesi Merkezi Araştırma ve Uygulama Laboratuvarındaki Toprak Laboratuvarı koşullarında temiz kurutma tepsilerine serilerek, taş ve kağıt 
parçacıkları ayıklanmış ve normal şartlar altında kurumaya bırakılmıştır. Alınan toprak örnekleri havada kuru hale geldikten sonra, $2 \mathrm{~mm}$ 'lik elekten geçirilerek fiziksel ve kimyasal analizler için hazırlanmıştır. Farklı tarım ürünlerinin ekili olduğu toprak örneklerinde; saturasyon çamuru otomatik büret ile (Demiralay, 1993), pH ölçümü saturasyon çamurunda pH metre ile (Black, 1965), elektriksel iletkenlik ölçümü saturasyon çamurunda EC metre ile (Thomas, 1996), tekstür tayini hidrometre yöntemi ile (Bouyocos, 1951), toplam kireç tayini Scheibler kalsimetresi ile (Gülçur, 1974), organik madde tayini yaş yakma metoduyla (Nelson ve Sommers, 1996), bitkiye yarayışlı kalsiyum (Ca), magnezyum (Mg), potasyum (K) ve sodyum (Na) $1 \mathrm{~N}$ amonyum asetat ile (Helmke ve Sparks, 1996), yarayışlı fosfor (P) elementi Kuo (1996) tarafından tanımlanan yöntemle, alınabilir demir (Fe), Bakır (Cu), Mangan ( $\mathrm{Mn}$ ) ve Çinko ( $\mathrm{Zn}$ ) mikro elementleri DTPA yöntemi ile (Lindsay ve Norvell, 1978) belirlenmiştir. Yapılan makro ve mikro besin elementi analizleri sonucu elde edilen homojen süzüklerde $\mathrm{Mg}, \mathrm{Na}, \mathrm{Fe}, \mathrm{Zn}, \mathrm{Cu}$ ve $\mathrm{Mn}$ elementleri konsantrasyonları atomik absorbsiyon spektrofotometresinde (Agilent, $240 \mathrm{AA}$ ), Ca ve K konsantrasyonları flame spektrometresinde (alev spektrometresi), P konsantrasyonları ise UV-VIS spektrofotometresinde belirlenmiştir.

Elde edilen verilerde korelasyon analizleri SPSS programında (IBM SPSS Advanced Statistics version 19.0.0) kullanılarak yapılmış, Düzgüneş ve ark. (1987)'e göre yorumlanmıştır.

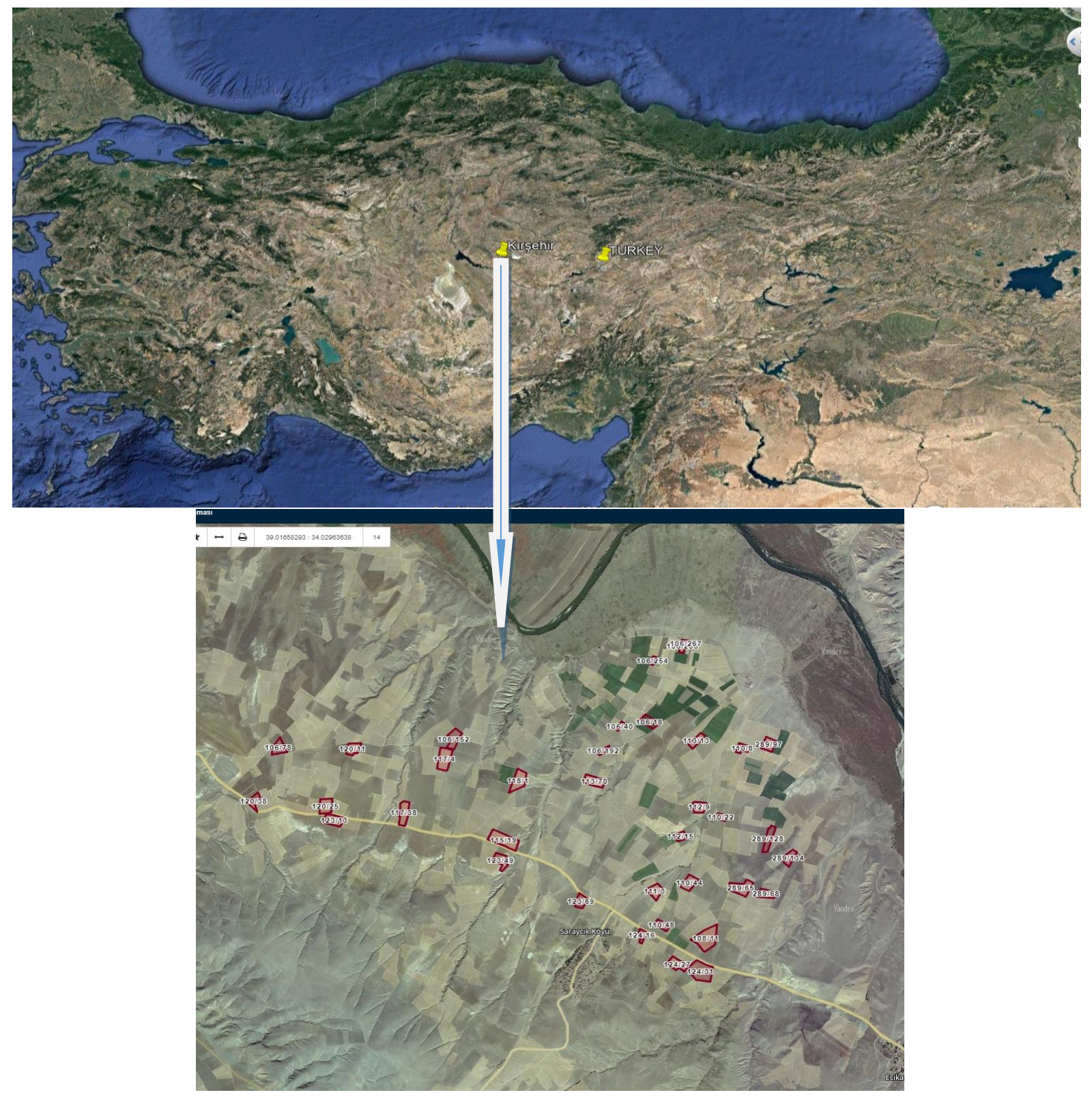

Şekil 1. Çalışmanın yapıldığı Kırşehir ili Saraycık köyü konumu ve toprak örnekleme noktaları. 


\section{Bulgular ve Tartışma}

Kırşehir ilinin Saraycık köyü ve çevresi arpa, buğday, nohut ve muhtelif ürün tarımının yapıldığı bir alandır. Bu bölgede hem kuru hem de sulu tarım yapılmaktadır. Çeşitli tarım yapılan toprakların bazı fiziksel ve kimyasal analizleri yapılmış ve analiz sonuçları Tablo 2'de gösterilmiştir (Tablo 2 ).

Suyla doygunluk yüzdesi ve tekstür tayini: Toprakların saturasyon değeri \% 43.90-62.65 arasında ve ortalama \% 53.35 olarak bulunmuştur (Tablo 2). Örneklerin kil oranları \% 1.98-25.00 arasında ve ortalama \% 15.65, silt miktarları \% 3.3828.60 arasında ve ortalama \% 10.06, kum içerikleri \% 64.54-83.45 ve ortalama \% 74.29 olarak saptanmıştır. Toprakların bünyesi kumlu tınlı olarak bulunmuştur. Analiz edilen toprakların, tarımsal üretim açısından fiziksel özellikleri uygun olup; toprakların su tutma kapasitesi, havalanması, gözenek yapısı ve su-hava dengesinin, bitki gelişmesi açısından uygun durumda olduğu söylenebilir. Toprak örneklerinde yapılan korelasyon analizi sonuçları Tablo 3'te verilmiştir. Yapılan istatistiki analizler sonucunda toprakların saturasyon değeri ile kum değeri arasında önemli negatif, kil değeri arasında pozitif ilişki bulunmuştur. Kaba bünyeli toprakların yüzey alanları ağır bünyeli topraklara göre daha düşük olduğundan dolayı, bunları su ile doygun hale getirmek için ağır bünyeli topraklara göre daha az su filmlerine gereksinim vardır. Kum oranı ne kadar fazla ise toprağın suyla doygunluk değerinin o kadar düşük, toprağı kil miktarı ne kadar fazla ise saturasyon değeri o kadar yüksek bulunmuştur. Dengiz ve ark. (2011)'nın Minöz havzası topraklarında yaptıkları araştırmada da benzer sonuca rastlanmış, topraktaki kil miktarındaki artış nedeniyle yüzey alanı artmış ve artan elektronegatif yükler sayesinde suyla doygunluk değerlerinin artmasına neden olmuştur. Toprakların saturasyon değeri ile değişebilir Ca ve Mg değerleri arasında önemli pozitif ilişki tespit edilmiştir. Aygün ve ark. (2013)'nın mera alanlarında yaptığı çalışmada da bahsi geçen parametreler arasında pozitif ilişki olduğu saptanmıştır.

pH: Toprakların pH değerleri 7.04 ile 8.16 arasında değişerek ortalama 7.77 ile hafif alkalin olarak bulunmuştur (Tablo 2). Ülgen ve Yurtsever (1995)'e göre yapılan sınıflandırmada; analiz edilen toprak örneklerinin \% 5.6'sının nötr, \% 94.4'ünün hafif alkali karakterli olduğu belirlenmiştir. Buğday, nohut, kavun-karpuz ekili olan tarım alanlarının
pH'sı hafif alkali, arpa ekili alan ise pH'sı nötr ve hafif alkali olarak bulunmuştur. Tüm toprak örneklerinde yapılan korelasyon analizleri sonucunda, $\mathrm{pH}$ değeri ile toplam kireç değerleri arasında önemli pozitif, alınabilir fosfor ve demir elementi ile negatif ilişki tespit edilmiştir (Tablo 3). Topraktaki kalsiyum karbonat miktarının artmasıyla birlikte toprak reaksiyonu 8.5'e kadar yükselmekte ve $\mathrm{Ca}^{++}$katyonu baskın durumda olmaktadır. Topraktaki serbest karbonat miktarı arttıkça $\mathrm{pH}$ değerinde yükselmeler olmakta, toprakta +2 değerlikli kalsiyum konsantrasyonu arttıkça ortamdaki alınabilir fosfor ve demir iyonları kalsiyum katyonu ile çözünemez formda bileşikler oluşturmaktadır (Özaytekin, 1996). Benzer bulgulara Aygün ve ark. (2013)'nın Bilecik ili topraklarında yaptıkları çalışmada da rastlanmıştır. Toprak $\mathrm{pH}^{\prime}$ sı ile organik madde arasında negatif korelasyon bulunmuştur. Toprağın pH değeri arttıkça toprak organik maddesinin azaldığı belirtilmiştir (Büyükgüner, 2007). Grerup ve ark. (2006), yaptıkları bir çalışmada tarım yapılan bir arazide meşe ormanına göre toprak pH'sının yükseldiğini bildirmişlerdir. Yapılan birçok çalışmada, araştırıcılar kurak ve yarı kurak iklim koşullarında, fosforun yüksek oranlarda kalsiyumfosfatlarca tutulduğunu, özellikle yüksek $\mathrm{pH}$ ve karbonat ile düşük organik madde içeriğinin fosforun çökelerek yarayışııı̆ının düşmesine neden olduğunu belirtmişlerdir (Sardi ve Csatho, 2002).

Toplam tuzluluk: Toprakların toplam tuz içeriği \% 0.007-0.047 arasında değişerek ve ortalama \% 0.016 ile tuzsuz bulunmuştur (Tablo 2). Richards (1954) tarafından yapılan sınıflandırmaya göre, çalışma alanı topraklarının tuzluluk yönünden herhangi bir sorunu bulunmadığı belirtilmiştir. Toplam tuz değeri ile değişebilir $\mathrm{Na}$ ve $\mathrm{K}$ değerleri arasında önemli pozitif, kum ile önemli negatif ilişki tespit edilmiştir (Tablo 3). Çoğunlukla topraklarda tuzlanmaya neden olan anyonlar klor, sülfat, karbonat, bikarbonat, nitrat olup, en yaygın katyonlar ise sodyum, kalsiyum, magnezyum ve potasyumdur. Bu anyon ve katyonların bir araya gelmesiyle tuzlar oluşmakta, toprakta bulunan pozitif yüklü iyonların mevcudiyeti ( $\mathrm{Ca}, \mathrm{Mg}, \mathrm{K}, \mathrm{Na}$ ) toprağın elektriksel iletkenliğini arttırmaktadır (Mc Neill, 1980; Li ve ark., 2008). Sudduth ve ark. (2003)'nın Missouri'de, Farahani ve ark. (2005)'nın Doğu Kolorado'da yaptıkları çalışmalarda benzer bulgulara rastlanmıştır. Toprakların tuz konsantrasyonu, geçirgen topraklarda ve yüksek kodlarda yıkanmanın etkisine bağı olarak daha düşük düzeylerde gözlenmektedir. 
Türk Tarım ve Doğa Bilimleri Dergisi 6(4): 636-647, 2019

Tablo 2. Çalışma sahasından alınan toprak örneklerinin bazı fiziksel ve kimyasal analiz sonuçları

\begin{tabular}{|c|c|c|c|c|c|c|c|c|c|c|c|c|c|c|c|c|c|}
\hline \multirow{2}{*}{$\begin{array}{c}\text { Toprak } \\
\text { No }\end{array}$} & Sat. & $\mathrm{pH}$ & EC & $\mathrm{CaCO}_{3}$ & OM & $\mathbf{P}_{\mathbf{2}} \mathbf{O}_{5}$ & $\mathrm{~K}_{2} \mathrm{O}$ & $\mathrm{Ca}$ & $\mathrm{Na}$ & Mg & Kil & Silt & Kum & $\mathrm{Fe}$ & $M n$ & $\mathrm{Zn}$ & $\mathrm{Cu}$ \\
\hline & $\%$ & & $\%$ & $\%$ & $\%$ & $\mathrm{~kg} \mathrm{da}^{-1}$ & $\mathrm{~kg} \mathrm{da}^{-1}$ & $\%$ & $\mathrm{mg} \mathrm{kg}^{-1}$ & $\%$ & $\%$ & $\%$ & $\%$ & $\begin{array}{l}\mathrm{mg} \\
\mathrm{kg}^{-1}\end{array}$ & $\begin{array}{l}\mathrm{mg} \\
\mathrm{kg}^{-1}\end{array}$ & $\begin{array}{l}\mathrm{mg} \\
\mathrm{kg}^{-1}\end{array}$ & $\begin{array}{l}\mathrm{mg} \\
\mathrm{kg}^{-1}\end{array}$ \\
\hline 1 & 52.550 & 7.785 & 0.009 & 10.793 & 1.859 & 4.707 & 122.966 & 0.825 & 312.850 & 0.033 & 17.701 & 13.099 & 69.199 & 0.343 & 1.739 & 0.226 & 0.932 \\
\hline 2 & 51.050 & 7.865 & 0.011 & 9.946 & 2.121 & 8.962 & 98.161 & 0.925 & 315.600 & 0.028 & 17.747 & 8.243 & 74.010 & 0.369 & 1.210 & 0.267 & 0.875 \\
\hline 3 & 54.050 & 7.505 & 0.010 & 4.021 & 1.743 & 7.082 & 81.978 & 0.900 & 297.450 & 0.036 & 17.709 & 5.077 & 77.214 & 0.669 & 1.820 & 0.252 & 0.660 \\
\hline 4 & 49.050 & 7.655 & 0.013 & 4.444 & 2.208 & 5.795 & 82.129 & 0.800 & 321.775 & 0.023 & 11.218 & 9.912 & 78.870 & 0.681 & 0.316 & 0.440 & 0.819 \\
\hline 5 & 52.800 & 7.735 & 0.010 & 3.668 & 2.150 & 5.499 & 126.748 & 0.875 & 312.425 & 0.034 & 15.377 & 8.716 & 75.907 & 0.321 & 4.957 & 0.550 & 0.847 \\
\hline 6 & 48.900 & 7.945 & 0.009 & 14.461 & 2.353 & 8.270 & 138.091 & 0.800 & 661.250 & 0.036 & 17.579 & 7.794 & 74.627 & 0.487 & 2.617 & 0.309 & 0.874 \\
\hline 7 & 52.600 & 7.665 & 0.011 & 12.486 & 2.673 & 6.983 & 122.210 & 0.875 & 281.875 & 0.025 & 17.668 & 7.986 & 74.346 & 0.489 & 1.493 & 0.772 & 0.815 \\
\hline 8 & 49.650 & 7.715 & 0.010 & 12.274 & 2.803 & 4.905 & 112.984 & 0.700 & 306.325 & 0.025 & 15.140 & 7.041 & 77.819 & 0.406 & 1.372 & 0.303 & 1.226 \\
\hline 9 & 46.550 & 7.795 & 0.009 & 8.253 & 2.034 & 7.478 & 135.218 & 0.700 & 308.700 & 0.027 & 13.359 & 9.043 & 77.598 & 0.243 & 3.682 & 0.368 & 1.152 \\
\hline 10 & 43.900 & 8.140 & 0.007 & 7.125 & 2.063 & 6.488 & 93.473 & 0.575 & 687.750 & 0.046 & 11.350 & 10.902 & 77.748 & 0.471 & 1.507 & 0.260 & 0.701 \\
\hline 11 & 50.650 & 7.805 & 0.008 & 15.167 & 2.237 & 5.301 & 103.153 & 0.775 & 309.050 & 0.025 & 13.185 & 12.127 & 74.687 & 0.342 & 1.166 & 0.593 & 0.737 \\
\hline 12 & 62.650 & 7.975 & 0.034 & 10.722 & 2.934 & 6.191 & 163.653 & 0.825 & 3090.500 & 0.060 & 16.399 & 13.102 & 70.499 & 0.443 & 3.106 & 0.574 & 0.967 \\
\hline 13 & 53.650 & 7.755 & 0.011 & 9.171 & 1.830 & 5.004 & 133.403 & 0.850 & 303.350 & 0.030 & 16.278 & 8.635 & 75.088 & 0.452 & 1.204 & 0.268 & 0.684 \\
\hline 14 & 47.650 & 7.915 & 0.012 & 8.959 & 1.743 & 7.478 & 127.806 & 0.650 & 384.225 & 0.025 & 11.410 & 10.960 & 77.630 & 0.465 & 1.283 & 0.331 & 0.817 \\
\hline 15 & 47.850 & 7.905 & 0.010 & 10.793 & 1.859 & 7.874 & 434.844 & 0.675 & 596.750 & 0.022 & 13.482 & 9.723 & 76.795 & 0.744 & 1.426 & 0.474 & 0.795 \\
\hline 16 & & 7.765 & 0.014 & & & & & & & & & & & & & & 0.819 \\
\hline 17 & 57.900 & 7.745 & 0.037 & 13.050 & 1.511 & 8.567 & 443.163 & 0.800 & 1027.750 & 0.084 & 17.617 & 13.462 & 68.920 & 0.261 & 1.753 & 0.477 & 0.793 \\
\hline 18 & 46.900 & 7.815 & 0.008 & 16.225 & 1.656 & 5.993 & 94.078 & 0.750 & 312.425 & 0.018 & 12.446 & 10.097 & 77.457 & 0.580 & 1.023 & 0.253 & 0.609 \\
\hline 19 & 60.650 & 7.875 & 0.047 & 9.523 & 1.685 & 6.488 & 459.800 & 0.875 & 1052.750 & 0.060 & 20.689 & 8.731 & 70.580 & 0.320 & 1.796 & 0.341 & 1.260 \\
\hline 20 & 53.650 & 8.015 & 0.018 & 11.569 & 2.063 & 5.400 & 177.416 & 0.775 & 1003.250 & 0.060 & 20.732 & 11.776 & 67.492 & 0.526 & 1.928 & 0.335 & 1.164 \\
\hline 21 & 58.650 & 8.155 & 0.026 & 16.930 & 2.004 & 20.740 & 399.300 & 0.725 & 998.750 & 0.114 & 18.319 & 6.636 & 75.045 & 0.355 & 3.952 & 0.310 & 1.169 \\
\hline 22 & 56.900 & 7.525 & 0.032 & 14.955 & 1.598 & 10.348 & 128.260 & 1.925 & 335.300 & 0.018 & 2.098 & 25.763 & 72.139 & 0.397 & 2.574 & 0.622 & 0.968 \\
\hline 23 & 51.950 & 7.565 & 0.009 & 12.274 & 1.627 & 9.655 & 174.089 & 0.775 & 490.250 & 0.261 & 16.471 & 7.494 & 76.035 & 0.445 & 3.520 & 0.664 & 1.300 \\
\hline 24 & 47.650 & 8.055 & 0.022 & 11.781 & 1.220 & 9.754 & 80.616 & 0.700 & 1762.250 & 0.202 & 10.150 & 6.404 & 83.446 & 0.854 & 5.600 & 0.645 & 1.130 \\
\hline 25 & 51.100 & 7.735 & 0.009 & 15.308 & 2.179 & 8.171 & 96.800 & 0.850 & 348.625 & 0.023 & 14.429 & 3.380 & 82.191 & 0.383 & 5.732 & 0.274 & 1.621 \\
\hline 26 & 50.800 & 7.665 & 0.016 & 12.063 & 3.050 & 7.874 & 94.683 & 0.800 & 309.625 & 0.023 & 14.539 & 6.771 & 78.689 & 0.369 & 4.733 & 0.304 & 1.279 \\
\hline 27 & 58.950 & 7.845 & 0.014 & 16.930 & 2.905 & 8.666 & 162.140 & 1.000 & 81.475 & 0.032 & 25.003 & 8.989 & 66.008 & 0.424 & 5.005 & 0.288 & 1.316 \\
\hline 28 & 51.850 & 7.045 & 0.014 & 1.497 & 3.341 & 23.016 & 153.670 & 0.425 & 96.175 & 0.053 & 16.296 & 6.756 & 76.948 & 0.969 & 0.378 & 0.407 & 1.881 \\
\hline 29 & 53.650 & 7.755 & 0.010 & 13.116 & 3.341 & 7.676 & 112.379 & 0.850 & 283.175 & 0.030 & 16.286 & 8.842 & 74.871 & 0.423 & 5.252 & 0.247 & 1.637 \\
\hline 30 & 56.650 & 7.780 & 0.011 & 15.397 & 2.905 & 8.666 & 121.605 & 0.950 & 216.950 & 0.031 & 20.428 & 5.766 & 73.806 & 0.390 & 4.392 & 0.196 & 1.348 \\
\hline 31 & 60.800 & 7.801 & 0.019 & 19.745 & 3.050 & 13.614 & 405.350 & 1.000 & 88.300 & 0.037 & 22.590 & 12.867 & 64.543 & 0.457 & 5.651 & 0.394 & 1.504 \\
\hline 32 & 53.300 & 7.545 & 0.026 & 16.725 & 2.469 & 4.608 & 113.438 & 2.275 & 193.675 & 0.009 & 1.984 & 28.602 & 69.414 & 0.473 & 3.287 & 0.130 & 0.961 \\
\hline
\end{tabular}




\begin{tabular}{|c|c|c|c|c|c|c|c|c|c|c|c|c|c|c|c|c|c|}
\hline 33 & 60.800 & 7.730 & 0.019 & 13.167 & 3.196 & 4.311 & 406.863 & 1.000 & 85.750 & 0.333 & 18.756 & 6.794 & 74.450 & 0.236 & 5.423 & 0.496 & 1.890 \\
\hline 34 & 57.800 & 7.855 & 0.014 & 12.028 & 3.196 & 5.103 & 399.300 & 3.475 & 95.600 & 0.330 & 16.485 & 6.785 & 76.730 & 0.372 & 2.867 & 0.189 & 1.205 \\
\hline 35 & 57.100 & 7.705 & 0.014 & 17.295 & 3.341 & 8.567 & 158.056 & 0.875 & 75.275 & 0.034 & 18.405 & 10.853 & 70.742 & 0.329 & 2.768 & .310 & 1.363 \\
\hline 36 & 58.100 & 7.735 & 0.019 & 24.412 & 2.847 & 6.983 & 140.814 & 0.950 & 293.025 & 0.031 & 18.458 & 12.085 & 69.457 & 0.512 & 1.834 & 0.293 & 1.324 \\
\hline Ortalama & 53.350 & 7.774 & 0.016 & 12.243 & 2.322 & 8.061 & 181.702 & 0.953 & 498.922 & 0.063 & 15.649 & 10.063 & 74.288 & 0.458 & 2.768 & 0.371 & 1.096 \\
\hline
\end{tabular}

$\left({ }^{*}=\mathrm{p}<0.05 .{ }^{* *}=\mathrm{p}<0.01\right)$ Sat.: Saturasyon yüzdesi, pH: Toprak reaksiyonu, EC: Toplam tuz, $\mathrm{CaCO}_{3}$ : Toplam kireç, OM: Organik madde, YP: Yarayışlı fosfor, K: Potasyum, Ca :Kalsiyum, Mg: Magnezyum, Na: Sodyum, Fe: Demir, Mn: Mangan, Zn: Çinko, Cu: Bakır.

Tablo 3. Çalışma alanı topraklarında yapılan bazı fiziksel ve kimyasal analizlerin korelasyon tablosu

\begin{tabular}{|c|c|c|c|c|c|c|c|c|c|c|c|c|c|c|c|c|c|}
\hline & Sat. & $\mathrm{pH}$ & EC & $\mathrm{CaCO}_{3}$ & OM & YP & K & $\mathrm{Ca}$ & $\mathrm{Mg}$ & $\mathrm{Na}$ & Kum & Kil & Silt & $\mathrm{Fe}$ & Mn & $\mathrm{Zn}$ & $\mathrm{Cu}$ \\
\hline Sat. & 1 & - & $.627^{* *}$ & $.370 * *$ & $.370 * *$ & - & $.534 * *$ & $.240 *$ & $.265^{*}$ & - & $-.646^{* *}$ & $.461^{* *}$ & - & $-.345^{* *}$ & $.313^{* *}$ & - & $.364^{* *}$ \\
\hline $\mathrm{pH}$ & - & 1 & - & $.244^{*}$ & $-.248^{*}$ & $-.237^{*}$ & - & - & - & $.462 * *$ & - & - & - & $-.267^{*}$ & - & - & $-.261 *$ \\
\hline EC & - & - & 1 & - & - & - & $.527^{* *}$ & - & - & $.519 * *$ & $-.388 * *$ & - & $.376^{* *}$ & - & - & - & - \\
\hline $\mathrm{CaCO}_{3}$ & - & - & - & 1 & - & - & - & - & - & - & $-.437 * *$ & - & $.265^{*}$ & $-.301^{*}$ & $.297^{*}$ & - & - \\
\hline OM & - & - & - & - & 1 & - & - & - & - & - & - & $.325^{* *}$ & - & - & $.250 *$ & - & $.489 * *$ \\
\hline YP & - & - & - & - & - & 1 & - & - & - & - & - & - & - & $.346^{* *}$ & - & - & $.340 * *$ \\
\hline K & - & - & - & - & - & - & 1 & - & $.442 *$ & - & $-.327^{* *}$ & $.350 * *$ & - & - & - & - & - \\
\hline $\mathrm{Ca}$ & - & - & - & - & - & - & - & 1 & $.306 * *$ & - & - & - & $.281^{*}$ & - & - & - & - \\
\hline $\mathrm{Mg}$ & - & - & - & - & - & - & - & - & 1 & - & - & - & $-.263^{*}$ & - & $.309 *$ & - & $.317^{* *}$ \\
\hline $\mathrm{Na}$ & - & - & - & - & - & - & - & - & - & 1 & - & - & - & - & - & $.327^{* *}$ & - \\
\hline Kum & - & - & - & - & - & - & - & - & - & - & 1 & $-.393 * *$ & $-.509 * *$ & $.306^{* *}$ & - & - & - \\
\hline Kil & - & - & - & - & - & - & - & - & - & - & - & 1 & $-.592 * *$ & - & - & - & $.299 *$ \\
\hline Silt & - & - & - & - & - & - & - & - & - & - & - & - & 1 & - & - & - & - \\
\hline $\mathrm{Fe}$ & - & - & - & - & - & - & - & - & - & - & - & - & - & 1 & $-.271^{*}$ & - & - \\
\hline $\mathrm{Mn}$ & - & - & - & - & - & - & - & - & - & - & - & - & - & - & 1 & - & $.486^{* *}$ \\
\hline $\mathrm{Zn}$ & - & - & - & - & - & - & - & - & - & - & - & - & - & - & - & 1 & - \\
\hline $\mathrm{Cu}$ & - & - & - & - & - & - & - & - & - & - & - & - & - & - & - & - & 1 \\
\hline
\end{tabular}

$\left(^{*}=p<0.05 .{ }^{* *}=p<0.01\right)$ Sat.: Saturasyon yüzdesi, $\mathrm{pH}$ : Toprak reaksiyonu, EC: Toplam tuz, $\mathrm{CaCO}_{3}$ : Toplam kireç, OM: Organik madde, YP: Yarayışlı fosfor, K: Potasyum, Ca :Kalsiyum, Mg: Magnezyum, Na: Sodyum, Fe: Demir, Mn: Mangan, Zn: Çinko, Cu: Bakır 
Toplam kireç: Toprakların toplam kireç içeriği incelendiğinde $\mathrm{CaCO}_{3}$ miktarının \%1.50-24.41 arasında ve ortalama olarak \%12.24 bulunmuştur (Tablo 2). Eyüpoğlu (1999) tarafından belirtilen sınıflandırmaya göre, araştırma topraklarının orta derecede kireçli olduğu tespit edilmiştir. Ekilen ürünlerden arpa ekili araziler kireçli ve orta kireçli, buğday, nohut, kavun ve karpuz ekili alanlar orta kireçli bulunmuştur. VII. Bölge topraklarının ortalama kireç oranı \%17 olduğu için fazla kireçli sınıfına dahil edilmiştir. Yapılan istatistiki analizler sonucunda, topraktaki toplam kireç ile kum içeriği arasında önemli negatif, toplam kireç ile silt içeriği ve $\mathrm{pH}$ arasında önemli pozitif ilişki tespit edilmiştir (Tablo 3). Bu verilere göre, çalışma alanlarındaki kirecin iri granüller halde bulunmayıp genellikle silt iriliğinde olduğunu göstermiştir. Benzer bulguya Mamedov ve ark. (2007) tarafından yapılan çalışmada da rastlanmıştır. Yüksek düzeylerdeki kireç miktarı toprakların pH'sını arttırmaktadır.

Organik madde: Toprakların organik madde içerikleri \%1.22 ile \%3.34 arasında değiştiği ve ortalama \%2.32 olduğu bulunmuştur (Tablo 2). Çalışma alanı topraklarının genel olarak orta seviyede organik madde içeriğine sahip olduğu saptanmıştır. Toprak örneklerinin \%19'u iyi, \%47'si orta ve \%34'ü az seviyede organik maddeye sahip olduğu tespit edilmiştir. Nohut ekili arazi toprağı orta seviyede, buğday ve arpa ekili arazi toprağı orta ve iyi seviyede organik maddeye sahipken kavunkarpuz ekili arazi az seviyede organik madde içeriğine sahiptir. Özellikle IV. Ve V. Bölge topraklarının az düzeyde organik madde içerdiği ama diğer bölge topraklarının orta düzeyde organik madde içerdiği görülmüştür. Çalışma alanında düşük seviyeli organik maddenin nedenleri arasında organik maddenin hızlı bir şekilde ayrışması ve mineralleşmesi yer almaktadır. Toprakların organik madde içeriği, toprakların özgül yüzey alanlarının artmasına neden olmaktadır. Organik madde miktarının düşük seviyede olması ile topraktaki azot oranının azaldığı belirtilmiştir. Yapılan istatistiki analizler sonucunda, toprakların organik madde içeriği ile saturasyon değeri arasında önemli pozitif ilişki tespit edilmiştir (Tablo 3). Malkawi ve ark. (1999)'nın ve Birol ve Bender Özenç (2011)'in yaptıkları araştırmada organik maddenin optimum su içeriğini arttırdığını ve daha yüksek nem içeriklerinde sature hale geldiğini belirtmişlerdir.

Yarayışlı fosfor: Araştırma alanı topraklarının yarayışlı fosfor içerikleri incelendiğinde 4.31-23.02 $k g$ da ${ }^{-1} \quad \mathrm{P}_{2} \mathrm{O}_{5}$ arasında değişkenlik gösterdiği, ortalama $8.061 \mathrm{~kg} \mathrm{da}^{-1} \mathrm{P}_{2} \mathrm{O}_{5}$ oranında fosfor olduğu saptanmıştır (Tablo 2). Eyüpoğlu (1999)'nun bildirdiği sınır değerler dikkate alındığında, analiz edilen toprakların \% 38.90'ının fosfor içeriği az (3-6 $\left.\mathrm{kg} \mathrm{da}^{-1}\right), \% 44.44^{\prime}$ ünün fosfor içeriği orta (6-9 kg da$\left.{ }^{1}\right), \% 8.33^{\prime}$ ünde yüksek (9-12 kg da-1), \%8.33'ünde çok yüksek ( $>12 \mathrm{~kg} \mathrm{da}^{-1}$ ) oranda fosfor bulundurduğu tespit edilmiştir. Buğday ekili arazilerin fosfor durumu az iken, nohut ve kavun-karpuz ekili arazilerin fosfor durumu orta, arpa ekili arazilerin durumu ise orta, yüksek ve çok yüksek olarak değişkenlik göstermiştir. III. Bölge topraklarının az seviyede fosfor içerdiği bulunmuştur. Bu sonuçlar dikkate alındığında genel olarak incelenen tarım alanı topraklarının fosfor düzeyi orta derecede olup, düzenli kontroller dahilinde fosfor ihtiyacının olduğu söylenebilir. Yapılan korelasyon analizi sonucunda yarayışlı fosfor ile $\mathrm{pH}$ arasında önemli negatif ilişki bulunmuştur (Tablo 3). Toprak reaksiyonunun alkali olduğu koşullarda alınabilir fosfor düzeyi olumsuz etkilenmektedir. Yapılan istatistiki analizler sonucunda, toprakların yarayışlı fosfor içerikleri ile yarayışlı demir ve yarayışlı bakır değerleri arasında önemli pozitif ilişki tespit edilmiştir. Topraktaki kireç miktarının artmasıyla birlikte toprak reaksiyonu yükselmekte ve $\mathrm{pH}$ değeri 8.5'e kadar kalsiyum katyonu baskın durumda bulunmaktadır. Toprakta $\mathrm{Ca}^{++}$konsantrasyonunun yükselmesiyle ortamdaki alınabilir fosfor iyonu $\mathrm{Ca}$ ile çözünemez formda bileşikler oluşturmaktadır. Karadavut ve ark. (2011), fiğ tarım alanlarında yapmış oldukları çalışmadaki topraklarda fosfor eksikliğinin bulunduğunu tespit etmişlerdir. Chhabra ve Thakur (2000) ile Mahmood ve ark. (2013) tarafından, toprakta bulunan yüksek kalsiyum konsantrasyonu çözünemez formda kalsiyum fosfatlar oluşturduğu ve fosfor elementinin kullanabilirliliğini azalttığı bildirilmiştir.

Değişebilir katyonlar ( $\mathrm{K}, \mathrm{Ca}, \mathbf{M g}, \mathbf{N a})$ : Toprakların alınabilir potasyum içerikleri incelendiğinde 80.62$459.80 \mathrm{~kg} \mathrm{da}^{-1} \mathrm{~K}_{2} \mathrm{O}$ aralığında ve ortalama 181.702 $\mathrm{kg} \mathrm{da}^{-1} \mathrm{~K}_{2} \mathrm{O}$ olduğu saptanmıştır (Tablo 2). Eyüpoğlu (1999)'nun açıkladığı sınır değerler dikkate alındığında çalışma alanı topraklarının tamamı potasyumca yüksek olduğu belirlenmiştir. Yapılan korelasyon analizi sonucunda değişebilir potasyum ile kum arasında önemli negatif ilişki, kil ile pozitif ilişki bulunmuştur (Tablo 3). Kum miktarının oldukça düşük olduğu tarım alanlarında potasyum miktarının fazlalığı beklenen bir sonuç olarak değerlendirilmektedir. Benzer sonuçlar Parlak ve ark. (2008), Ateş ve Turan (2015) ve Karadavut ve ark. (2011) tarafından da elde edilmiştir. Bu sonuçlar dikkate alındığında topraktaki potasyum miktarı ile kaba taneli partikül miktarının birbirlerini ters yönde etkiledikleri görülmektedir. 
Toprakların kalsiyum değeri \%0.425-\%3.475 arasında değiştiği ve ortalama $\% 0.953$ olduğu bulunmuştur. Çalışma alanı tarım alanı topraklarının tamamının kalsiyumca zengin olduğu tespit edilmiştir. Değişebilir kalsiyum ile silt arasında önemli pozitif ilişki bulunmuştur (Tablo 3).

Örneklerin magnezyum içerikleri \%0.018$\% 0.333$ aralığında ve ortalama $\% 0.063$ olduğu tespit edilmiştir. Toprak örneklerinin \%2.68'nin magnezyum değeri düşük iken \%97.32'sinin magnezyum değeri yüksek olarak bulunmuştur. Değişebilir magnezyum ile silt arasında önemli negatif, magnezyum ile mangan ve bakır arasında önemli pozitif ilişki bulunmuştur (Tablo 3).

Toprakların değişebilir sodyum değeri 75.275-3090.500 mg kg-1 aralığında ve ortalama $498.922 \mathrm{mg} \mathrm{kg}^{-1}$ olarak bulunmuştur. Değişebilir sodyum ile çinko arasında önemli pozitif ilişki bulunmuştur (Tablo 3). Horneck ve ark. (2007), toprakta $\mathrm{Ca}, \mathrm{Na}, \mathrm{K}$ ve $\mathrm{Mg}$ gibi katyonların artmasıyla toprakta tuzluluğun meydana geldiği ve bu durumda EC değerinin arttığını, sodyum elementinin topraklarda $\mathrm{pH}^{\prime} \mathrm{y}$ ı yükselten ve alkalilik oluşturan bir element olduğunu rapor etmişlerdir.

Bu sonuçlar dikkate alındığında kalsiyum ve magnezyum katyonları ile potasyum ve sodyum elementleri içerikleri toprak örneklerinde oldukça yüksek seviyede bulunmuş ve bahsi geçen katyonlar karbonatların çözünmesinde etkili olmuştur.

Mikro elementler (Fe, Cu, Mn, Zn): Çalışma alanından alınan toprak örneklerindeki mikro besin elementlerinin dağılımı oldukça farklııı göstermiştir. Çalışma alanı topraklarının alınabilir demir değeri en düşük $0.24 \mathrm{mg} \mathrm{kg}^{-1}$, en yüksek 0.97 $\mathrm{mg} \mathrm{kg} \mathrm{kg}^{-1}$ ve ortalama $0.458 \mathrm{mg} \mathrm{kg}^{-1}$ olarak bulunmuştur (Tablo 2). Bu değerlere göre; arpa, buğday, nohut ve kavun-karpuz ekili toprakların tamamı (\%100) demir elementi bakımından düşük düzeyde bulunmuş ve çalışma alanında demir eksikliğinin olduğu tespit edilmiştir. İncelenen topraklardaki demir içeriği ile mangan değeri arasında önemli negatif ilişki tespit edilmiştir (Tablo 3).

Incelenen tarım alanı topraklarının bakır içeriği en düşük $0.61 \mathrm{mg} \mathrm{kg}^{-1}$, en yüksek $1.89 \mathrm{mg} \mathrm{kg-}$ ${ }^{1}$ ve ortalama $1.096 \mathrm{mg} \mathrm{kg}^{-1}$ olarak bulunmuştur. Bu değerlere göre; arpa, buğday, nohut ve kavunkarpuz ekili toprakların tamamı bakır bakımından yeterli düzeyde bulunmuştur. İncelenen topraklardaki bakır içeriği ile $\mathrm{pH}$ değeri arasında olumsuz ama önemli ilişki olduğu gözlenirken saturasyon, yarayışlı fosfor, magnezyum, mangan, kil ve organik madde miktarları arasında olumlu ve önemli ilişkiler tespit edilmiştir (Tablo 3). Benzer bulgulara Karadavut ve ark. (2011)'nın fiğ tarım alanlarında yaptıkları makro ve mikro besin elementleri çalışmalarında rastlanmıştır.

Toprakların alınabilir mangan miktarı en düşük $0.32 \mathrm{mg} \mathrm{kg}^{-1}$, en yüksek $5.73 \mathrm{mg} \mathrm{kg}^{-1}$ ve ortalama $2.768 \mathrm{mg} \mathrm{kg}{ }^{-1}$ olarak tespit edilmiştir. Çalışmadaki topraklarında genellikle mangan noksanlığının olduğu belirlenmiştir. Özellikle buğday ekili arazilerde mangan düşük seviyede bulunmuştur. Toprakların alınabilir mangan içeriği ile saturasyon, kireç, organik madde, magnezyum ve bakır arasında önemli ve olumlu ilişki gözlenirken, demir ile önemli ama olumsuz ilişki olduğu tespit edilmiştir (Tablo 3). Karadavut ve ark. (2011)'nın Konya ili Ereğli, Karapınar, Akören ve Seydişehir ilçelerinde yürüttükleri çalışmada elde ettikleri bulgular ile bizim çalışmamızda elde ettiğimiz bulgular aynı paralelliktedir.

Çalışma alanı topraklarının alınabilir çinko değeri en düşük $0.13 \mathrm{mg} \mathrm{kg}^{-1}$, en yüksek $0.77 \mathrm{mg} \mathrm{kg}^{-}$ ${ }^{1}$ ve ortalama $0.371 \mathrm{mg} \mathrm{kg}^{-1}$ olduğu tespit edilmiştir. Bu sonuçlara göre incelenen topraklarda genellikle çinko elementinin düşük seviyede olduğu bulunmuştur. Topraklardaki çinko eksikliği genel olarak Türkiye'nin yarısında karşımıza sorun olarak çıkmaktadır. Bu \%50'lik kısmın \%92'si ise İç Anadolu bölgesine ait olduğu açıklanmıştır (Yılmaz, 2007). Kırşehir ilinin genelindeki tarım alanı topraklarında bu sorun ile karşılaşmamız beklenen bir sonuç olarak değerlendirilebilir. Yapılan korelasyon analizi sonucunda çinko ile sodyum değeri arasında önemli pozitif ilişki bulunmuştur (Tablo 3). Karadavut ve ark. (2011)'nın fiğ tarım alanlarından ve Zengin ve ark. (2003)'nın Konya ilinde yaptıkları çalışmalardan elde ettikleri bulgular ile benzerlik göstermektedir.

\section{Sonuç ve Öneriler}

Kırşehir ilinin merkez ilçesine bağı bulunan Saraycık köyü tarım alanı topraklarının verimlilik düzeylerini belirlemek amacıyla yapılan bu çalışmada bazı fiziksel ve kimyasal analizler sonucu elde edilen veriler ışığında; alan topraklarının özellik kazanmasında kalkerli ana materyallerin etkin olduğu, düzensiz ve az yağışların yıkanmaya etkisinin yeterli bulunmadığı, yüzey şekillerinin ve yüksekliğinin yerel alanlarda toprak içi drenaja etkili olduğu tespit edilmiştir. Yağış miktarının düşük olması kalsik horizonun toprak yüzeyine yakın oluşmasına neden olmuştur. Düşük yağış rejiminin görüldüğü alanlarda fiziksel ayrışma koşulları baskın olup kimyasal ve biyolojik olayları etkilemektedir.

Tuzluluk problemi bulunmayan çalışma alanı topraklarının kumlu tınlı yapıda ve toprak reaksiyonunun genellikle hafif alkalin özellikte olduğu, organik madde ve toplam kireç içeriklerinin orta seviyede bulunduğu saptanmıştır. Organik maddece zengin toprak elde etmek için organik gübre, ahır gübresi ve toprak düzenleyicilerden bazı 
organo-mineral gübrelerin kullanılması toprak verimliliğinin yanı sıra bitki besleme bakımından önem taşıyabilir. Değiştirilebilir katyon (Ca, Mg, K, $\mathrm{Na)}$ değerleri yüksek seviyede bulunmuş ve bu katyonlar topraktaki karbonatların çözünmesinde etkili olmuştur. Alan topraklarının potasyum miktarının yüksek olması ile birlikte topraklara potasyumlu gübre uygulanmasına ihtiyaç olmadığı tespit edilmiştir. Toprakların fosfor düzeyinin orta seviyede olduğu görülmüştür. Toprakların mikro besin elementleri bakımından alınabilir demir, çinko ve mangan elementi miktarlarının az/çok az seviyede, alınabilir bakır elementinin yeterli düzeyde bulunduğu tespit edilmiştir. Çalışma alanı toprağının demir ve çinko ihtiyacı giderilebilmeli, azotlu ve fosforlu gübrelerin uygun cins ve miktarları gübreleme programlarına alınabilmelidir. Çiftçilerin yılda bir defa toprak tahlili yaptırmaları, toprağın ihtiyacına göre kimyasal uygulama yapmaları gerektiği sonucuna varılmıştır.

\section{Teşekkür}

Bu çalışma Kırşehir Ahi Evran Üniversitesi Bilimsel Araştırma Projeleri Koordinasyon Birimi tarafından ZRT. A4. 18. 010 nolu proje olarak desteklenmiş ve Kırşehir Ahi Evran Üniversitesi Merkezi Araştırma ve Uygulama Laboratuvarında yürütülmüştür.

\section{Kaynaklar}

Abacı Bayar, A.A. 2016. Doğu Akdeniz Bölgesinde yer alan sulak alanlarda oluşan toprakların özellikleri, verimlilik düzeyleri ve sorunları. Kahramanmaraş Sütçü İmam Üniversitesi, Fen Bilimleri Ens. Doktora Tezi, Toprak Bilimi ve Bitki Besleme Anabilim Dalı. Kahramanmaraş.

Ateş, K. ve Turan, V. 2015. Bingöl ili merkez ilçesi tarım topraklarının bazı özellikleri ve verimlilik düzeyleri. Türkiye Tarımsal Araştırmalar Dergisi. Turk J. Agric. Res., TÜTAD ISSN: 2148-2306, 2: 108-113.

Aygün, C., Kara, İ., Sever, A.L., Erdoğdu, İ., Atalay, A.K., Avağ, A., Mermer, A., Özaydınlı, A., Yıldız, H., Urla, Ö., Aydoğdu, M., Ünal, E., Aydoğmuş, O., Dedeoğlu, F., Tuğaç, M.G., Torunlar, H., Cebel, H., Başkan, O., Keçeci, M. ve Depel, G. 2013. Bilecik ili mera topraklarının bazı fiziksel ve kimyasal özelliklerinin belirlenmesi. III. Ulusal Toprak ve Su Kaynakları Kongresi 22-24 Ekim 2013Tokat.

Başar, H. 2001. Bursa ili topraklarının verimlilik durumlarının toprak analizleri ile incelenmesi. Uludağ Üniversitesi Ziraat Fakültesi Dergisi, 15(2): 69-83.
Birol, Y. ve Bender Özenç, D. 2011. Fındık zuruf kompostunun sıkıştırılmış killi tınlı bir toprağın fiziksel özellikleri üzerine etkisi. Ulusal Toprak ve Su Sempozyumu 25-27 Mayıs 2011, Ankara.

Black, C.A. 1965. Methods of Analysis Agreon., No:

9, Ame. Soc. Agr., Madison Wisconsin, USA.

Bouyocous, G.L. 1951. A Recalibration of hydrometer method for making mechanical analysis of soils. Agron. J. 43; s.434-438.

Büyükgüner, E. 2007. Farklı kullanım altındaki toprakların fiziksel ve kimyasal özelliklerinin incelenmesi. Gaziosmanpaşa Üniversitesi Fen Bilimleri Ens., Toprak Anabilim Dalı, 76. s

Chhabra, R. ve Thakur, N.P. 2000. Long-Term study on phosphorus fertilization for rice-wheat cropping system in an alkali soils in the indogangetic plains. In: Long-term Soil Fertility Experiments in Rice-Wheat Cropping Systems (Rice-Wheat Consortium), pp: 3139. Abrol, I.P. (ed.). Paper Series 6, New Delhi, India.

Çakıcı, H., Çiçekli, M. ve Arslan, H. 2012. Bağyurdu İzmir yöresi kiraz plantasyonlarının beslenme durumu. Ege Üniversitesi Ziraat Fakültesi Dergisi, 49(1): 7-15.

Çimrin, K.M. ve Boysan, S. 2006. Van yöresi tarım topraklarının besin elementi durumları ve bunların bazı toprak özellikleriyle ilişkileri. Yüzüncü Yıl Üniversitesi Ziraat Fakültesi Tarım Bilimleri Dergisi, 16(2): 105-111.

Demiralay, i. 1993. Toprak Fiziksel Analizleri. Atatürk Üniversitesi Ziraat Fakültesi Yayınları No: 143, ss: 131, Erzurum.

Demirer, T., Kaleli, Ş. ve Öztokat Kuzucu, D.C. 2003. A study to determine fertility status in the Çanakkale Lapseki agricultural areas, Turkey. Journal of Arid Environments, 54: 485-493.

Dengiz, O., Gülser, C., Erel, A., Demir, Z. ve İç, S. 2011. Minöz havzası temel toprak özellikleri, sınıflandırılması ve haritalanması. Toprak ve Su Sempozyumu 2011.

Dinç, U., Şenol, S., Sayın, M., Kapur, S., Güzel, N., Derici, R., Yeşilsoy, M.Ş., Yegingil, İ., Sarı, M., Kaya, Z., Aydın, M., Kettaş, F., Berkman, A., Çolak, A.K., Yılmaz, K., Tunçöğüs, B., Özbek, H., Gülüt, K.Y., Karaman, C., Öztürk, N. ve Kara, E.E. 1988. Harran Ovası Toprakları. Çukurova Üniversitesi Ziraat Fakültesi Toprak Bölümü. TÜBiTAK-TOAG 534 Nolu Proje, Adana.

Düzgüneş, O., Kesici, T. ve Gürbüz, F. 1987. Araştırma ve Deneme Metotları (İstatistik Metotları-2). A.Ü.Z.F. Yayınları, No: 1021. Ankara.

Eyüpoğlu, F. 1999. Türkiye Topraklarının Verimlilik Durumu. Köy Hizmetleri Genel Müdürlüğü, 
Toprak ve Gübre Araştırma Enstitüsü Yayınları, Genel Yayın No: 220, Teknik Yayın No: T-67.

Farahani H.J., Buchleiter, G.W. ve Brodahl, M.K. 2005. Characterization of apparent soil electrical conductivity variability in irrigated sandy and non-saline fields in Colorado. Transactions of the ASAE, 48(1): 155-168.

Grerup, U.F., Brink, D.J. ve Brunet, J. 2006. Land use effects on soil N, P.C and pH persist over 4080 years of forest growth on agricultural soils. Forest Ecology and Management, 225: 74-81.

Gülaç, Z.N. 2011. Sivas îli hafik ilçesi tarım işletmelerinde toprak analizi uygulamalarının benimsenmesi ve yayılması üzerine bir araştırma. Yüksek Lisans Tezi, Gaziosmanpaşa Üniversitesi, Fen Bilimleri Enstitüsü, Tarım Ekonomisi Anabilim Dalı, 132 s., Tokat.

Gülçur, F. 1974. Toprağın fiziksel ve kimyasal analiz metotları. İstanbul Üniversitesi Orman Fakültesi Yayınları, İ.Ü. Yayın No: 1970, O.F. Yayın No: 201, Kutulmuş Matbaası, İstanbul.

Helmke, P.A. ve Sparks, D.L. 1996. Lithium, Sodium, Potassium, Rubidium, and Calcium, in Sparks, D.L., (Ed) Methods of Soil Analysis, Part 3, Chemical Methods, SSSA Book Series Number 5, SSSA., Madison,WI, pp. 551-574.

Horneck, D.A., Ellsworth, J.W., Hopkins, B.G., Sullivan, D.M. ve Stevens, R.G. 2007. Managing salt Affected Soils for Crop Production. A Pacific Northwest Extension. Oregon State University.

Jackson, M.L. 1958. Soil Chemical Analysis. Englewood Cliffs, NJ: Prentice- Hall. Inc.

Kadakal, S. 1992. Tekirdağ yöresinde buğday bitkisine toprak analiz raporlarına göre ve analiz yapılmadan uygulanan gübrelemenin fosfor yönünden karşılaştırılması. Trakya Üniversitesi. Fen Bilimleri Enstitüsü, Lisans Üstü Tezi. Tekirdağ.

Karadavut, U., Palta, Ç., Bitgi, S., Okur, O. ve Çarkacı, A. 2011. Konya ilinde fiğ tarımı yapılan bazı alanlarında makro ve mikro besin elementi içeriklerinin belirlenmesi. Iğdır Üniversitesi Fen Bilimleri Enstitüsü Dergisi, 1(3): 105-109.

Kızılaslan, N., Kızılaslan, H. ve Candemir, S. 2014. Kahramanmaraş ilçesinde çiftçilerin gübreleme alışkanlıklarının belirlenmesi, XI. Ulusal Tarım Ekonomisi Kongresi. 3-5 Eylül, Samsun, 2: 660-666.

Kuo, S.1996. Phosphorus in D.L. sparks (ed) methods of soil analysis, Part 3, Chemical Methods, SSSA Book Series Number 5, SSSA., Madison,WI, pp. 869-921.
Li, Z., Liu, X., Zhang, X. ve Li, W. 2008. Infiltration of melting saline ice water in soil columns: consequences on soil moisture and salt content. Agricultural Water Management, 95(4): 98-502.

Lindsay, W.L. ve Norvel, W.A. 1978. Development of DTPA soil test for $\mathrm{Zn}, \mathrm{Fe}, \mathrm{Mn}$ and $\mathrm{Cu}$. Soil Sci. Amer. J., 42(3): 421-28.

Mahmood, I.A., Ali, A., Aslam, M., Shahzad, A., Sultan, T. ve Hussain, F. 2013. Phosphorus availability in different salt-affected soils as influenced by crop residue incorporation. Internatıonal Journal of Agrıculture \& Biology ISSN Print: 1560-8530; ISSN Online: 1814-9596 12-905/2013/15-3-472-478.

Malkawi, A., Alawneh, A. ve Abu-Safaqah, O. 1999. Effects of organic matter on the physical and the physicochemical properties of an illitic soil. Applied Clay Science, 14:257-278.

Mamedov, A.l., Beckmann, S., Huang, C. ve Levy, G.J. 2007. Aggregate stability as affected by polyacrylamide molecular weight, soil texture, and water quality. Soil Sci. Soc. Am. J., 71: 1909-1918.

McNeill, J.D. 1980. Electrical Conductivity of Soil and Rocks. Tech. Note TN-5. Geonics Ltd., Mississauga, Ontario, Canada.

Nelson, D.W. ve Sommers, L.E. 1996. Total carbon, organic carbon, and organic matter. In D.L. Sparks (ed) method of soil analysis: chemical methods. Part 3. SSSA, Madison, WI., pp. 961-1011.

Oruç, E. 1994. Tokat İli Kazova yöresi'nde kimyasal gübrelerin tedarik ve kullanımı üzerine bir araştırma. Yüksek Lisans Tezi, Gaziosmanpaşa Üniversitesi, Fen Bilimleri Enstitüsü, Tarım Ekonomisi Anabilim Dalı, 123 s., Tokat.

Özaytekin, H.H. 1996. Konya-Ereğli civarındaki organik toprakların morfolojik, fiziksel ve kimyasal özellikleri ve oluşumu üzerine bir araştırma. Yüksek Lisans Tezi Selçuk Üniversitesi Fen bilimleri Enstitüsü Toprak Anabilim Dalı, 113 s., Konya.

Özyazıcı, M.A., Dengiz, O. ve Sağlam, M. 2013. Artvin ilinde yonca (Medicago sativa L.) tarımı yapılan toprakların verimlilik durumu ve potansiyel beslenme problemlerinin ortaya konulması. Artvin Çoruh Üniversitesi Orman Fakültesi Dergisi, 14(2): 225-238.

Parlak, M., Fidan, A., Kızılcık, İ. ve Koparan, H. 2008. Eceabat ilçesi (Çanakkale) tarım topraklarının verimlilik durumlarının belirlenmesi. Ankara Üniversitesi Ziraat Fakültesi Tarım Bilimleri Dergisi, 14(4): 394400. 
Richards, L.A. 1954. Diagnosis and improvement of saline and alkaline soils. U.S.A: U.S. Department of Agriculture, Handbook 60.

Sardi, K. ve Csatho, P. 2002. Studies the phosphorus adsorption of different soil types and nutrient levels. 17th WCSS, 14-21 August 2002, Thailand.

Sudduth, K.A., Kitchen, N.R., Bollero, G.A., Bullock, D.G. ve Wiebold, W.J. 2003. Comparison of electromagnetic induction and direct sensing of soil electrical conductivity. Agron. J., 95: 472-482 (this issue).

Thomas, G.W. 1996. Soil pH and Acidity. pp. 475491. In D.L. Sparks (ed) method of soil analysis: chemical methods. Part 3. SSSA, Madison, WI.

Tunçtürk, M. ve Yıldırım, B. 2004. Effects of different forms and doses of nitrogen fertilizers on safflower (Carthamus tinctorius L.). Pakistan Journal of Biological Sciences, 7(8): 13851389.

Tümsavaş, Z. ve Aksoy, E. 2008. Bursa yöresi Rendzina büyük toprak grubu topraklarının bazı özellikleri ve besin maddesi içerikleri. Uludağ Üniversitesi Ziraat Fakültesi Dergisi, 22(1): 95-106.

Unay, B. 2007. Türkiye'de gübre sanayinin gelişimi ve iktisadi performansı. Yüksek Lisans Tezi, Marmara Üniversitesi, Sosyal Bilimler Enstitüsü, İktisat Anabilim Dalı, 228. İstanbul.

Ülgen, N. ve Yurtsever, N. 1995. Türkiye gübre ve gübreleme rehberi (4. Baskı). T.C. Başbakanlık Köy Hizmetleri Genel Müdürlüğü Toprak ve Gübre Araştırma Enstitüsü Müdürlüğü Yayınları, Genel Yayın No: 209, Teknik Yayınlar No: T.66, Ankara.

Yaraş, K. ve Daşgan, H.Y. 2012. Sera koşullarında toprağa uygulanan mikronize-bentonitlikükürt ve organik maddenin toprak ph'sı, domatesin bitki büyümesi, verimi ve meyve kalitesi üzerine etkisi. Tarım Bilimleri Araştırma Dergisi, 5(1): 175-180.

Yılmaz, A. 2007. İç Anadolu Bölgesi topraklarındaki çinko noksanlığının bitki besleme ve insan üzerine etkileri. Bahri Dağdaş Uluslararası Tarımsal Araştırma Enstitüsü Kayıtları. Konya.

Zengin, M., Çetin, Ü., Ersoy, İ. ve Özaytekin, H.H. 2003. Beyşehir yöresi tarım topraklarının verimlilik durumlarının belirlenmesi. SÜ Ziraat Fakültesi Dergisi, 17(31): 24-30. 